\title{
Brain-Derived Neurotrophic Factor Is Required for the Neuroprotective Effect of Mifepristone on Immature Purkinje Cells in Cerebellar Slice Culture
}

\author{
Jennifer Rakotomamonjy ${ }^{1}$ and Abdel Mouman Ghoumari ${ }^{2, *(D)}$ \\ 1 Department of Physiology, Northwestern University Feinberg School of Medicine, 303 East Chicago Avenue, \\ Chicago, IL 60611, USA; jennifer.rakotomamonjy@northwestern.edu \\ 2 INSERM UMR 1195 Inserm and Universities Paris-Sud and Paris-Saclay, 80 rue du Général Leclerc, \\ 94276 Kremlin-Bicêtre, France \\ * Correspondence: abdel.ghoumari@inserm.fr
}

Received: 26 December 2018; Accepted: 10 January 2019; Published: 12 January 2019

\begin{abstract}
Endogenous $\gamma$-aminobutyric acid (GABA)-dependent activity induces death of developing Purkinje neurons in mouse organotypic cerebellar cultures and the synthetic steroid mifepristone blocks this effect. Here, using brain-derived neurotrophic factor (BDNF) heterozygous mice, we show that BDNF plays no role in immature Purkinje cell death. However, interestingly, BDNF haploinsufficiency impairs neuronal survival induced by mifepristone and $\mathrm{GABA}_{\mathrm{A}}$-receptors antagonist (bicuculline) treatments, indicating that the underlying neuroprotective mechanism requires the neurotrophin full expression.
\end{abstract}

Keywords: Purkinje cells; mifepristone; BDNF; $\mathrm{GABA}_{\mathrm{A}}$ receptors; MAP-kinase

\section{Introduction}

Purkinje cells die in cerebellar organotypic slice cultures when tissue is taken from animals between postnatal day (P)1 and P7, with a culminating point at P3 [1]. This period coincides with important developmental events such as neuronal migration and formation of synaptic connections [2,3]. In our previous study, we showed that Purkinje cell death following slice culture process was due, in part, to the $\gamma$-aminobutyric acid (GABA)-ergic network activity [4], known to be excitatory at this developmental stage [5,6]. When exposed to bicuculline, a GABA $\mathrm{A}$ receptor antagonist, Purkinje cells survived [4]. This was the first demonstration that cerebellar slices from P3 rats or mice can release endogenous GABA, which induces strong GABAergic activity in the Purkinje cell network. We thus established that the neuroprotective effect of the synthetic steroid mifepristone [7] was due to its ability to depolarize Purkinje cell membrane potential to a value above chloride reversal potential, shunting GABAergic conductance $[4,8]$.

Neurotrophins, such as brain-derived neurotrophic factor (BDNF), are essential for Purkinje cell development. BDNF is synthesized and released in an activity-dependent manner [9], and binds namely to its high-affinity receptor, tropomyosin receptor kinase B (TrkB) [10]. BDNF and TrkB are highly expressed in the postnatal cerebellum, including during the synaptogenesis stage [11,12]. They have been reported to promote dendritic growth [13,14], cerebellar development and foliation [15], Purkinje cell neuronal activity, and formation of functional neural circuits [16-18]. Besides these trophic effects, BDNF can also exacerbate excitotoxic insults to motor, cortical, and cerebellar neurons [19-22]. BDNF expressions markedly increase in many cell types following tissue injury, tissue insult, and aging $[23,24]$. Nevertheless, treating slice cultures of developmental mouse cerebellum with an antibody against BDNF or BDNF peptide did not affect the survival of Purkinje cells [25]. 
In developing neurons, $\mathrm{BDNF}$ expression is facilitated by $\mathrm{GABA}_{\mathrm{A}}$ receptor activation [26]. In turn, the neurotrophin can modulate GABAergic activity $[27,28]$. BDNF has usually been identified as a potentiator of neurotransmitter release, GABA included [29], in diverse neurodegenerative contexts [30]. Given the mutual influence between GABA and BDNF, we sought to identify if the neurotrophin plays a role in immature Purkinje cell death in slice culture in synergy with, or independently of, $\mathrm{GABA}_{\mathrm{A}}$ receptors activity and the neuroprotective effect of the steroid mifepristone. Our results show that, surprisingly, in our culture model, BDNF haploinsufficiency substantially decreases the neuroprotective effect of the steroid mifepristone on Purkinje neurons. This suggests that a full expression of BDNF is critical to prevent the neurotoxicity induced by the GABAergic network activity.

\section{Results}

\subsection{The Neurotrophin BDNF Is Not Involved in Immature Purkinje Cell Survival in Organotypic Cerebellar} Slice Culture

To determine the involvement of BDNF in Purkinje cell survival in slice cultures, we first tested if the expression levels of BDNF could affect survival during postnatal development (P0-P8) in wild type (WT) and heterozygous (HTZ) BDNF mice. Cerebellar slices taken from P0, P3, and P8 WT and HTZ mouse pups were put in culture for 7 days without any treatment and then immunolabeled with the Purkinje cell marker, calbindin. At P0 we counted $162 \pm 31$ and $142 \pm 13$ Purkinje cells for WT and HTZ, respectively (Figure 1). Purkinje cell numbers decreased at P3 to reach $42 \pm 6$ and $35 \pm 6$ for WT and HTZ, respectively (Figure 1). Later at P8, Purkinje cells survival improved as we counted $735 \pm 97$ and $640 \pm 43$ Purkinje cells in WT and HTZ cerebellar slice culture, respectively (Figure 1). Our results show that BDNF expression levels do not affect Purkinje cell survival during the first postnatal week.

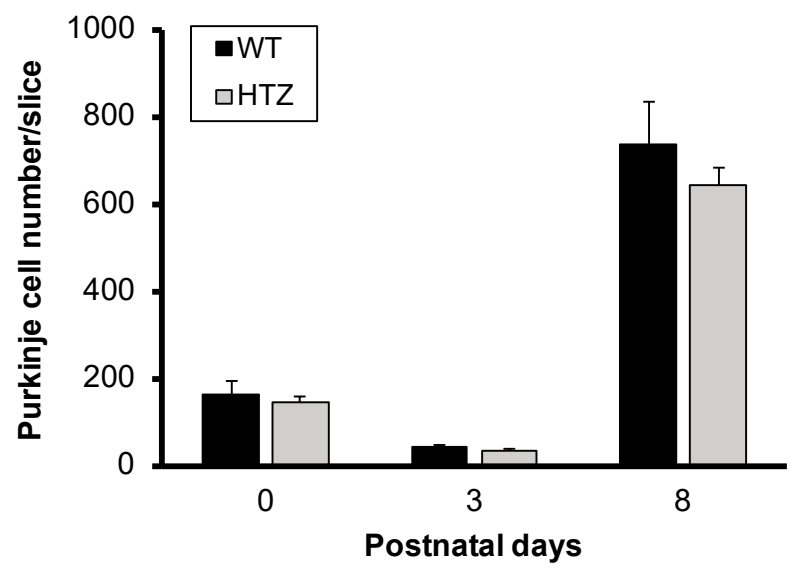

Figure 1. Brain-derived neurotrophic factor (BDNF) is not involved in immature Purkinje cell survival. Quantitative analysis of Purkinje cell survival in cerebellar slice culture from wild type (WT) or BDNF heterozygous (HTZ) mouse pups at different ages (postnatal-day 0: P0; -day 3: P3 and -day 8: P8).

\subsection{BDNF Haploinsufficiency Impairs Neuroprotection by Bicuculline in Cerebellar Slice Culture}

Previously, we have demonstrated that adding BDNF to slice cultures had no effect on Purkinje cell survival [25], presumably because of the difficulty for BDNF peptide to reach Purkinje cells in thick $(350 \mu \mathrm{m})$ cerebellar slices.

To investigate if BDNF is implicated in Purkinje cell death by GABAergic network neurotoxicity, cerebellar slices were taken from P3 wild type and BDNF heterozygous mice and put in organotypic

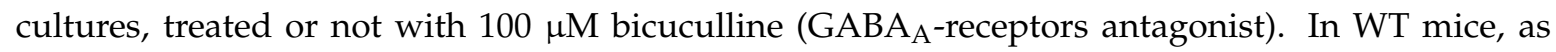
previously shown [4], a large number of Purkinje cells survived with treatment (Figure 2A-C). Surprisingly, the neuroprotective effect of bicuculline showed a $57 \%$ decrease in HTZ mice. We 
counted $381 \pm 62$ Purkinje cells/slice in treated slices from WT mice, and $165 \pm 39$ Purkinje cells/slice in treated slices from HTZ mice (Figure 2A,D,E).
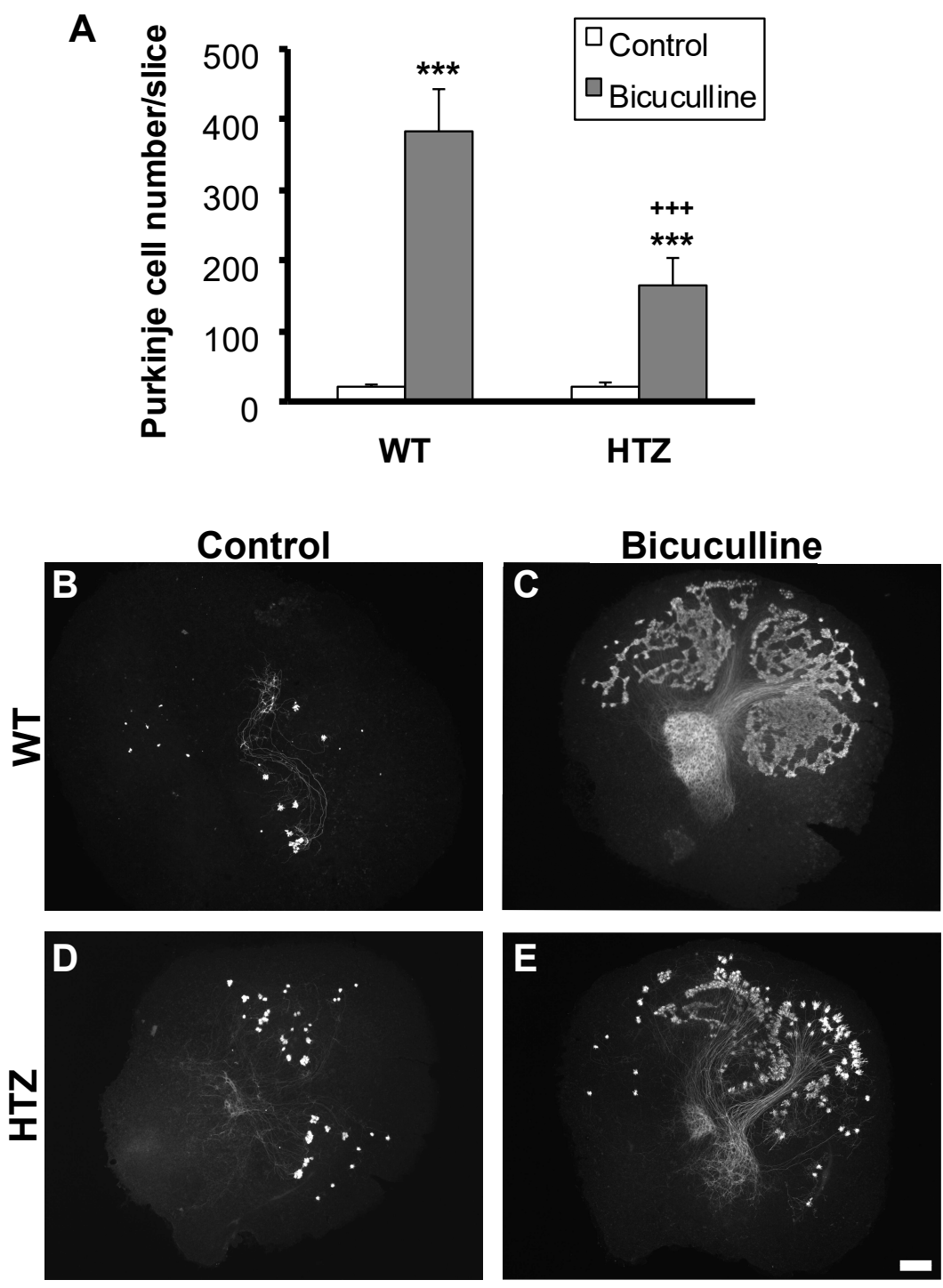

Figure 2. The neuroprotective effect of $\mathrm{GABA}_{\mathrm{A}}$ receptor inhibition is half-lost in BDNF heterozygous mice. (A) Quantitative analysis of Purkinje cell survival in cerebellar slice cultures from wild type or BDNF heterozygous mice, treated with $100 \mu \mathrm{M}$ bicuculline; (B-E) images of Purkinje cells labeled by Calbindin. (B,D) Control slices from wild type and BDNF heterozygous mice, respectively; $(\mathrm{C}, \mathrm{E})$ Bicuculline treated slices from wildtype and BDNF heterozygous mice, respectively. Scale bar, $200 \mu \mathrm{m}$. Data are expressed as mean of at least 3 independent experiments + SEM. ${ }^{* * *} p<0.001$ between control and treated slices, $+++p<0.001$ between WT and HTZ treated slices.

\subsection{The Neuroptrophin BDNF Full Expression Is Necessary for Neuroprotection with Mifepristone}

In light of these unexpected results obtained using bicuculline, we investigated if the synthetic steroid mifepristone, known to exert its neuroprotective effect via shunting of GABAergic conductance, would mimic bicuculline results. For this purpose, P3 cerebellar slices were taken from WT or BDNF HTZ mice and treated, or not, in organotypic cultures with $50 \mu \mathrm{M}$ mifepristone. Next, we investigated if the decrease of endogenous BDNF could affect the survival of Purkinje cells under the steroid treatment. With the steroid, a large number of Purkinje cells survived (Figure $3 \mathrm{~A}-\mathrm{C}$ ), as previously shown [7]. We counted $1689 \pm 6$ Purkinje cells in treated slices from WT mice, while slices from HTZ mice presented only $141 \pm 33$ Purkinje cells/slice (Figure 3D,E). 

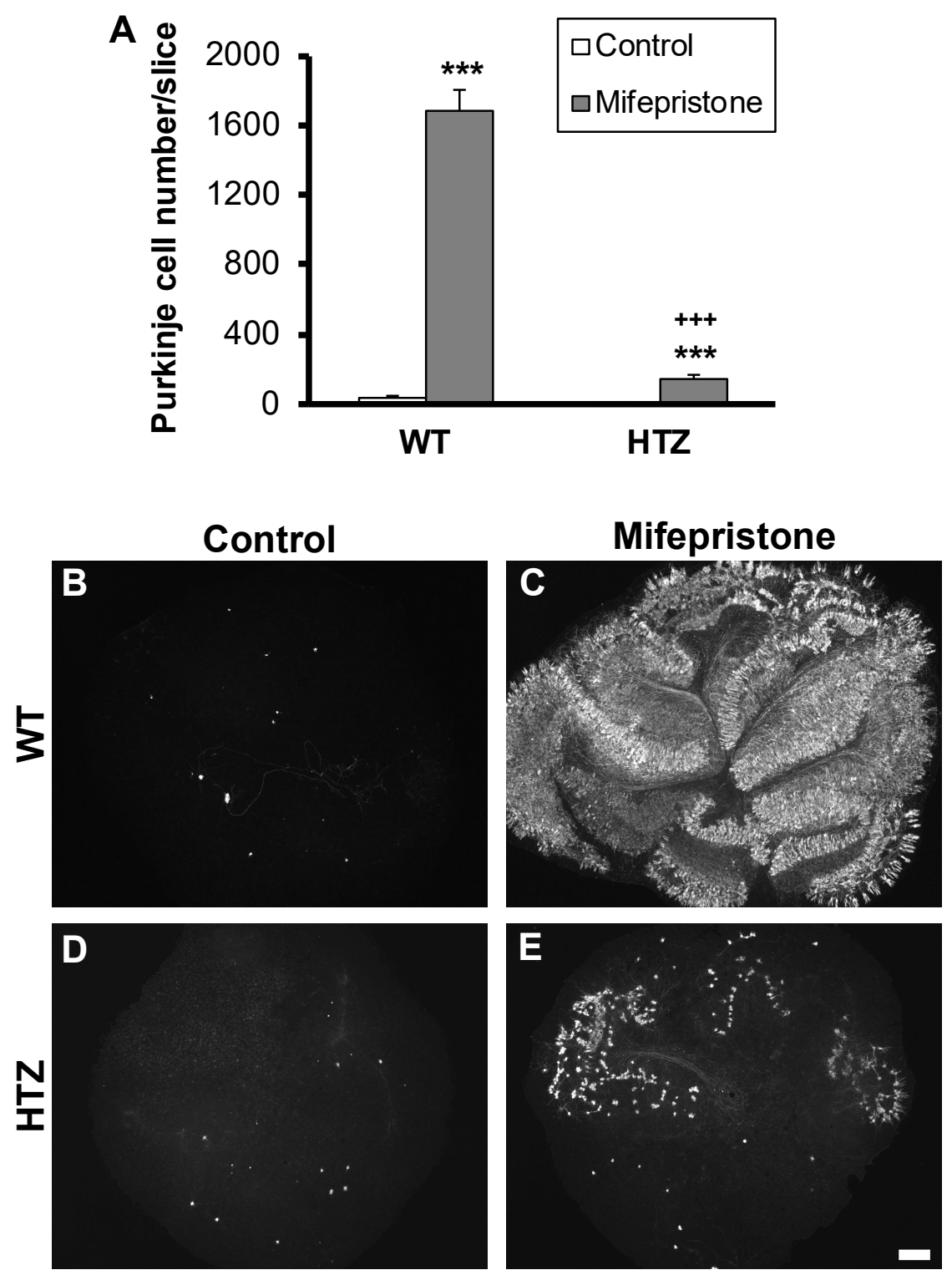

Figure 3. The neurotrophic factor BDNF is necessary for neuroprotection to occur with mifepristone. (A) Quantitative analysis of Purkinje cell survival in wild type or BDNF heterozygous mice treated or not with mifepristone $(50 \mu \mathrm{M})$; (B,D) Control slices from wild type and BDNF heterozygous mice, respectively; (C,E) mifepristone treated slices from wild type and BDNF heterozygous mice, respectively. Scale bar, $200 \mu \mathrm{m}$. Data are expressed as mean of at least 3 independent experiments + SEM. ${ }^{* * *} p<0.001$ between control and treated slices. $+++p<0.001$ between WT and HTZ treated slices.

2.4. Neuroprotective Effect of the p38 MAP-Kinase Inhibitor, SB203580, Is Not Affected by BDNF Haploinsufficiency

We demonstrated in previous studies that Purkinje cell death involved p38 MAP-kinase signaling and that both neuroprotective treatments with bicuculline and mifepristone could prevent its activation [4]. Thus, we tested if p38 MAP-kinase signaling was BDNF-dependent. Cerebellar slice cultures were treated with the specific p38 MAP-kinase inhibitor SB203580 $(20 \mu \mathrm{M})$ at P3. SB203580 induced high Purkinje cell survival as we counted about $106 \pm 17$ and $486 \pm 40$ Purkinje cells in untreated and SB203580 treated slices from WT mice, respectively (Figure 4). Furthermore, slices from HTZ mice presented $88 \pm 18$ and $438 \pm 47$ Purkinje cells/slice in untreated and SB203580 treated slices from HTZ mice, respectively (Figure 4). 


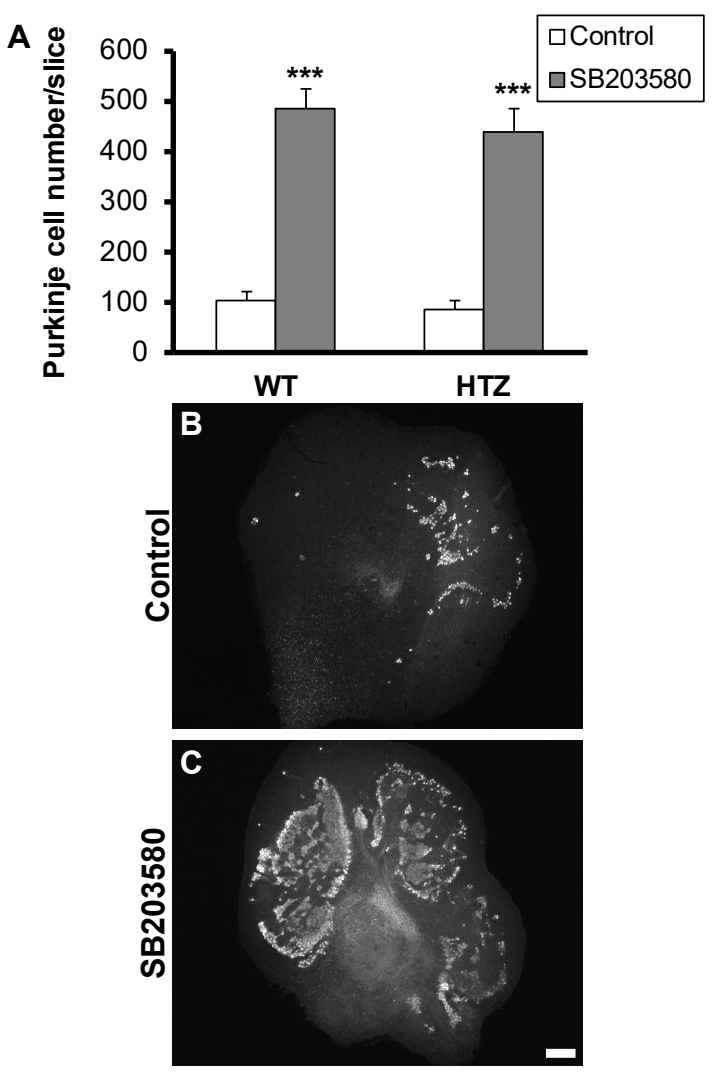

Figure 4. Neuroprotective effect of the p38 MAP-Kinase inhibitor, SB203580, is not affected by BDNF expression levels. (A) Quantitative analysis of Purkinje cell survival in wild type or BDNF heterozygous mice treated with SB203580 $(20 \mu \mathrm{M})$; (B) Representative control slices from wild type or BDNF heterozygous mice; (C) Representative slice from wild type or BDNF heterozygous mice treated with SB203580 $(20 \mu \mathrm{M})$. Scale bar, $200 \mu \mathrm{m}$. Data are expressed as mean of at least three independent experiments + SEM. ${ }^{* * *} p<0.001$ between control and treated slices.

\section{Discussion}

During the postnatal period, the neurotrophin BDNF is highly expressed in the cerebellum, permitting its development and foliation as well as Purkinje cell dendritic growth and neuronal activity [11-18]. In the present study, we did not use Knock-out (KO) BDNF mice because of their early postnatal mortality. We used HTZ BDNF mice in cerebellar slice culture and found that the presence or absence of BDNF could not affect Purkinje cell survival during postnatal development (P0-P8), suggesting no role for BDNF in Purkinje cell survival in our model. These results confirm our previous studies, indicating that treating slices with an antibody against BDNF, or BDNF peptide, did not affect the survival of Purkinje cell [25]. One could suggest that BDNF is not implicated in Purkinje cell death. Surprisingly, the neurotrophin is absolutely needed for bicuculline- and mifepristone-induced Purkinje cell survival. This is consistent with other studies demonstrating the necessity of BDNF to support neuron survival [31]. For example, BDNF prevents the low potassium-induced-death of cultured cerebellar granule cells [32] and mediates the neuroprotective effect of estradiol on Purkinje cell following ethanol treatment [33]. In addition, the potential benefits of BDNF have been reported in several pathological conditions in other regions of the nervous system [34].

The relationship between BDNF expression and GABAergic transmission during central nervous system development are well documented [30]. GABA $\mathrm{A}_{\mathrm{A}}$ excitatory actions have been reported to increase BDNF expression [26]. Inversely, the neurotrophin can differentially modulate $\mathrm{GABA}_{\mathrm{A}}$ transmission during development, in CA1 pyramidal neurons [28] and Purkinje cells [35]. It has also been reported that BDNF can increase the number of synapses from GABAergic neurons or the 
number of cell surface $\mathrm{GABA}_{\mathrm{A}}$ receptors in cultures from rat visual cortex [36,37], or increase GABA release in a model of cortical neuron culture from postnatal day 2 rats [38]. Thus, synergistic actions between BDNF and GABA and their increasing releases could actually enhance Purkinje cell death in our model.

Moreover, we previously showed that p38 MAP-kinase was activated after culture, peaking at $30 \mathrm{~min}$, and downregulated by both mifepristone and $\mathrm{GABA}_{\mathrm{A}}$ receptor inhibition [4]. Given this activation has been reported as necessary for in vivo BDNF production in rat hippocampus [39] or BDNF synthesis and release by microglia [40], it could represent a key factor in the neuroprotection process involving BDNF in our culture model. However, the neuroprotective effect of the pro-apoptotic MAP-kinase p38 inhibition does not need BDNF. It may be independent from the steroid mifepristone and $\mathrm{GABA}_{\mathrm{A}}$ receptor inhibition effect underlying mechanisms, or the recruitment of MAP-kinase signaling would intervene downstream of BDNF actions. This is possible because previous studies demonstrated that BDNF could inhibit activation of p38 MAP-kinase and, thus, prevented cerebellar granule neurons death [41].

In summary, this is the first study showing a relevant intervention of neurotrophin BDNF in the mechanism of action of the steroid mifepristone. The presence of BDNF is not implicated in Purkinje cell death but it is necessary for the mifepristone neuroprotective effect. Hence, the final conclusion on a role of BDNF in the neuroprotective effect of mifepristone still requires further experiments to address how BDNF can impact on mifepristone-induced changes of Purkinje cell membrane polarity and on GABA-induced toxicity.

\section{Materials and Methods}

\subsection{Animals and Organotypic Slice Culture}

All procedures were performed according to the European Communities Council Directive (2010/63/EU, adopted on 22 September 2010) for the care and use of laboratory animals. All mice were bred in our animal facility under a $12 \mathrm{~h}$ dark/light cycle with food and water ad libitum. BDNF +/ - (HTZ) mice were purchased from Jackson laboratories (Bar Harbor, Maine, USA) and C57Bl/6 wild type (WT) mice from Janvier (Le Genest St Isle, France). Mouse pups at postnatal days 0 (P0), 3 (P3) and 8 (P8) were used for organotypic culture of cerebellar slices.

For all animals, after decapitation, brains were dissected out into cold Gey's balanced salt solution with $5 \mathrm{mg} / \mathrm{mL}$ glucose (GBSS-Glu, Sigma-aldrich, St. Quentin Fallavier, France), and meninges were removed. Parasagittal slices (350 $\mu \mathrm{m}$ thick) were cut on a Macllwain tissue chopper and separated into cold GBSS-Glu. The slices were cultured on the membrane of a $30 \mathrm{~mm}$ Millipore culture insert (Millicell, Millipore, Bedford, MA, USA; pore size $0.4 \mu \mathrm{m}$ ) and maintained in culture 6-well plates containing $1 \mathrm{~mL}$ of medium at $35{ }^{\circ} \mathrm{C}$ in an atmosphere of humidified $5 \% \mathrm{CO}_{2}$. The medium was composed of 50\% basal medium with Earl's salt, 25\% Hank's balanced salts solution, 25\% horse serum (Invitrogen, Gaithersburg, MD, USA), L-glutamine (1mM), and $5 \mathrm{mg} / \mathrm{mL}$ glucose.

The principal chemical compounds used were the synthetic steroid RU486 (Mifepristone: 11ß-(4-dimethylamino)phenyl-17 $\beta$-hydroxy-17-(1-propynyl)estra-4,9-dien-3-one, Sigma), Bicuculline methiodide $\left(\mathrm{GABA}_{\mathrm{A}}\right.$-receptor antagonist, Sigma) and the MAP-kinase p38 inhibitor SB203580(4[5-(4-Fluorophenyl)-2-[4-(methylsulfonyl)phenyl]-1H-imidazol-4-yl]pyridine, Bio-Techne Ltd., Lille, France). Cerebellar slices were exposed to these compounds only for the first two days of culture, and medium was replaced after two days without newly adding the respective steroids or drugs. Five days later, cultures were fixed for later immunostaining.

\subsection{Immunofluorescence Analysis}

For the detection of Purkinje cells, immunofluorescence for the calbindin D-28k was performed. The cultures were fixed in $4 \%$ paraformaldehyde in phosphate buffer $(0.1 \mathrm{M}), \mathrm{pH} 7.4$, for $1 \mathrm{~h}$ at room temperature. After washing in PBS, slices were taken off the Millicell and processed for 
immunohistochemistry. Slices were incubated for $1 \mathrm{~h}$ in a phosphate buffered saline blocking solution $(0.12 \mathrm{M}, \mathrm{pH} 7.4)$ containing $0.9 \% \mathrm{NaCl}, 0.25 \%$ Triton $\mathrm{X}-100,0.1 \%$ gelatine, $0.1 \%$ sodium azide (PBSGTA) and lysine $(0.1 \mathrm{M})$. Then, slices were incubated with rabbit polyclonal antibody against calbindin D-28k $\left(1 / 10000\right.$, Swant, Bellinzona, Switzerland) in PBSGTA overnight at $4{ }^{\circ} \mathrm{C}$. Slices were next incubated with secondary goat anti-rabbit CY3-labeled antibody (1/250 dilution, Jackson Immunoresearch Laboratories, Inc., West Grove, PA, USA) for $2 \mathrm{~h}$ at room temperature in PBSGTA. Slices were washed in PBS and then mounted in Fluoromount-G mounting medium (Clinisciences, France). Fluorescent images were acquired using a fluorescence microscope (Zeiss, Oberkochen, Germany), with the image analyzing system Axiovision 4 (Zeiss, Oberkochen, Germany).

To quantify the Purkinje cell survival in the cultures, each cerebellar slice culture was photographed and the total number of surviving Purkinje cells per slice was counted.

\subsection{Statistical Analysis}

Statistical parameters including the definitions and exact value of $n$, deviations, $p$ values, and the types of the statistical tests are reported in the corresponding figure legends. Statistical analysis was carried out using Prism 6 (GraphPad Software). All statistical comparisons were conducted on data originating from at least three or more biologically independent experimental samples. Statistical comparisons between two groups were performed using an unpaired $t$ test. Data are expressed as means \pm SEM. Differences were considered significant with $p<0.05$.

Author Contributions: Conceptualization, J.R. and A.M.G.; methodology, J.R.; validation, A.M.G.; formal analysis, J.R.; investigation, J.R. and A.M.G.; data curation, J.R. and A.M.G.; writing-original draft preparation, J.R.; writing—review and editing, A.M.G.; supervision, A.M.G.; project administration, A.M.G.

Funding: This research received no external funding.

Conflicts of Interest: The authors declare no conflict of interest.

\section{References}

1. Dusart, I.; Airaksinen, M.S.; Sotelo, C. Purkinje cell survival and axonal regeneration are age dependent: An in vitro study. J. Neurosci. 1997, 17, 3710-3726. [CrossRef] [PubMed]

2. Bosman, L.W.; Konnerth, A. Activity-dependent plasticity of developing climbing fiber-Purkinje cell synapses. Neuroscience 2009, 162, 612-623. [CrossRef] [PubMed]

3. Sotelo, C. Development of "Pinceaux" formations and dendritic translocation of climbing fibers during the acquisition of the balance between glutamatergic and gamma-aminobutyric acidergic inputs in developing Purkinje cells. J. Comp. Neurol. 2008, 506, 240-262. [CrossRef]

4. Rakotomamonjy, J.; Levenes, C.; Baulieu, E.E.; Schumacher, M.; Ghoumari, A.M. Novel protective effect of mifepristone on detrimental GABAA receptor activity to immature Purkinje neurons. FASEB J. 2011, 25, 3999-4010. [CrossRef] [PubMed]

5. Eilers, J.; Plant, T.D.; Marandi, N.; Konnerth, A. GABA-mediated $\mathrm{Ca}^{2+}$ signalling in developing rat cerebellar Purkinje neurones. J. Physiol. 2001, 536, 429-437. [CrossRef] [PubMed]

6. Watt, A.J.; Cuntz, H.; Mori, M.; Nusser, Z.; Sjostrom, P.J.; Hausser, M. Traveling waves in developing cerebellar cortex mediated by asymmetrical Purkinje cell connectivity. Nat. Neurosci. 2009, 12, 463-473. [CrossRef] [PubMed]

7. Ghoumari, A.M.; Dusart, I.; El-Etr, M.; Tronche, F.; Sotelo, C.; Schumacher, M.; Baulieu, E.E. Mifepristone (RU486) protects Purkinje cells from cell death in organotypic slice cultures of postnatal rat and mouse cerebellum. Proc. Natl. Acad. Sci. USA 2003, 100, 7953-7958. [CrossRef] [PubMed]

8. Ghoumari, A.M.; Piochon, C.; Tomkiewicz, C.; Eychenne, B.; Levenes, C.; Dusart, I.; Schumacher, M.; Baulieu, E.E. Neuroprotective effect of mifepristone involves neuron depolarization. FASEB J. 2006, 20, 1377-1386. [CrossRef]

9. Poo, M.M. Neurotrophins as synaptic modulators. Nat. Rev. Neurosci. 2001, 2, 24-32. [CrossRef] 
10. Klein, R.; Nanduri, V.; Jing, S.A.; Lamballe, F.; Tapley, P.; Bryant, S.; Cordon-Cardo, C.; Jones, K.R.; Reichardt, L.F.; Barbacid, M. The trkB tyrosine protein kinase is a receptor for brain-derived neurotrophic factor and neurotrophin-3. Cell 1991, 66, 395-403. [CrossRef]

11. Bosman, L.W.; Hartmann, J.; Barski, J.J.; Lepier, A.; Noll-Hussong, M.; Reichardt, L.F.; Konnerth, A. Requirement of TrkB for synapse elimination in developing cerebellar Purkinje cells. Brain Cell Biol. 2006, 35, 87-101. [CrossRef] [PubMed]

12. Lindholm, D.; Hamner, S.; Zirrgiebel, U. Neurotrophins and cerebellar development. Perspect. Dev. Neurobiol. 1997, 5, 83-94. [PubMed]

13. Gorski, J.A.; Zeiler, S.R.; Tamowski, S.; Jones, K.R. Brain-derived neurotrophic factor is required for the maintenance of cortical dendrites. J. Neurosci. 2003, 23, 6856-6865. [CrossRef]

14. Zhou, X.P.; Wu, K.Y.; Liang, B.; Fu, X.Q.; Luo, Z.G. TrkB-mediated activation of geranylgeranyltransferase I promotes dendritic morphogenesis. Proc. Natl. Acad. Sci. USA 2008, 105, 17181-17186. [CrossRef]

15. Schwartz, P.M.; Borghesani, P.R.; Levy, R.L.; Pomeroy, S.L.; Segal, R.A. Abnormal Cerebellar Development and Foliation in $\mathrm{BDNF}^{-/-}$Mice Reveals a Role for Neurotrophins in CNS Patterning. Neuron 1997, 19, 269-281. [CrossRef]

16. Cheng, Q.; Yeh, H.H. PLCgamma signaling underlies BDNF potentiation of Purkinje cell responses to GABA. J. Neurosci. Res. 2005, 79, 616-627. [CrossRef] [PubMed]

17. Kafitz, K.W.; Rose, C.R.; Thoenen, H.; Konnerth, A. Neurotrophin-evoked rapid excitation through TrkB receptors. Nature 1999, 401, 918-921. [CrossRef]

18. Choo, M.; Miyazaki, T.; Yamazaki, M.; Kawamura, M.; Nakazawa, T.; Zhang, J.; Tanimura, A.; Uesaka, N.; Watanabe, M.; Sakimura, K.; et al. Retrograde BDNF to TrkB signaling promotes synapse elimination in the developing cerebellum. Nat. Commun. 2017, 8, 195. [CrossRef]

19. Hu, P.; Kalb, R.G. BDNF heightens the sensitivity of motor neurons to excitotoxic insults through activation of TrkB. J. Neurochem. 2003, 84, 1421-1430. [CrossRef]

20. Ishikawa, Y.; Ikeuchi, T.; Hatanaka, H. Brain-derived neurotrophic factor accelerates nitric oxide donor-induced apoptosis of cultured cortical neurons. J. Neurochem. 2000, 75, 494-502. [CrossRef]

21. Kim, S.H.; Won, S.J.; Sohn, S.; Kwon, H.J.; Lee, J.Y.; Park, J.H.; Gwag, B.J. Brain-derived neurotrophic factor can act as a pronecrotic factor through transcriptional and translational activation of NADPH oxidase. J. Cell Biol. 2002, 159, 821-831. [CrossRef] [PubMed]

22. Morrison, M.E.; Mason, C.A. Granule neuron regulation of Purkinje cell development: Striking a balance between neurotrophin and glutamate signaling. J. Neurosci. 1998, 18, 3563-3573. [CrossRef] [PubMed]

23. Jiang, C.; Zhang, S.; Liu, H.; Guan, Z.; Zeng, Q.; Zhang, C.; Lei, R.; Xia, T.; Wang, Z.; Yang, L.; et al. Low glucose utilization and neurodegenerative changes caused by sodium fluoride exposure in rat's developmental brain. Neuromol. Med. 2014, 16, 94-105. [CrossRef] [PubMed]

24. Chen, J.; Niu, Q.; Xia, T.; Zhou, G.; Li, P.; Zhao, Q.; Xu, C.; Dong, L.; Zhang, S.; Wang, A. ERK1/2-mediated disruption of BDNF-TrkB signaling causes synaptic impairment contributing to fluoride-induced developmental neurotoxicity. Toxicology 2018, 410, 222-230. [CrossRef] [PubMed]

25. Ghoumari, A.M.; Wehrle, R.; De Zeeuw, C.I.; Sotelo, C.; Dusart, I. Inhibition of protein kinase C prevents Purkinje cell death but does not affect axonal regeneration. J. Neurosci. 2002, 22, 3531-3542. [CrossRef]

26. Obrietan, K.; Gao, X.B.; Van Den Pol, A.N. Excitatory actions of GABA increase BDNF expression via a MAPK-CREB-dependent mechanism-A Positive Feedback Circuit in Developing Neurons. J. Neurophysiol. 2002, 88, 1005-1015. [CrossRef]

27. Gubellini, P.; Ben-Ari, Y.; Gaiarsa, J.L. Endogenous neurotrophins are required for the induction of GABAergic long-term potentiation in the neonatal rat hippocampus. J. Neurosci. 2005, 25, 5796-5802. [CrossRef]

28. Mizoguchi, Y.; Ishibashi, H.; Nabekura, J. The action of BDNF on GABA(A) currents changes from potentiating to suppressing during maturation of rat hippocampal CA1 pyramidal neurons. J. Physiol. 2003, 548, 703-709. [CrossRef]

29. Goggi, J.; Pullar, I.A.; Carney, S.L.; Bradford, H.F. Modulation of neurotransmitter release induced by brain-derived neurotrophic factor in rat brain striatal slices in vitro. Brain Res. 2002, 941, 34-42. [CrossRef]

30. Kim, J.; Lee, S.; Kang, S.; Kim, S.H.; Kim, J.C.; Yang, M.; Moon, C. Brain-derived neurotropic factor and GABAergic transmission in neurodegeneration and neuroregeneration. Neural Regen. Res. 2017, $12,1733-1741$. 
31. Han, B.H.; Holtzman, D.M. BDNF protects the neonatal brain from hypoxic-ischemic injury in vivo via the ERK pathway. J. Neurosci. 2000, 20, 5775-5781. [CrossRef] [PubMed]

32. Kubo, T.; Nishimura, S.; Murasugi, T.; Kaneko, I.; Meguro, M.; Marumoto, S.; Kogen, H.; Koyama, K.; Oda, T.; Nakagami, Y. 6-Ethyl-N,N'-bis(3-hydroxyphenyl)[1,3,5]triazine-2,4-diamine (RS-0466) enhances the protective effect of brain-derived neurotrophic factor on amyloid beta-induced cytotoxicity in cortical neurones. Pharmacol. Toxicol. 2003, 93, 264-268. [CrossRef] [PubMed]

33. Firozan, B.; Goudarzi, I.; Elahdadi Salmani, M.; Lashkarbolouki, T.; Rezaei, A.; Abrari, K. Estradiol increases expression of the brain-derived neurotrophic factor after acute administration of ethanol in the neonatal rat cerebellum. Eur. J. Pharmacol. 2014, 732, 1-11. [CrossRef] [PubMed]

34. Zhao, H.; Alam, A.; San, C.Y.; Eguchi, S.; Chen, Q.; Lian, Q.; Ma, D. Molecular mechanisms of brain-derived neurotrophic factor in neuro-protection: Recent developments. Brain Res. 2017, 1665, 1-21. [CrossRef] [PubMed]

35. Huang, Y.; Ko, H.; Cheung, Z.H.; Yung, K.K.; Yao, T.; Wang, J.J.; Morozov, A.; Ke, Y.; Ip, N.Y.; Yung, W.H. Dual actions of brain-derived neurotrophic factor on GABAergic transmission in cerebellar Purkinje neurons. Exp. Neurol. 2012, 233, 791-798. [CrossRef] [PubMed]

36. Mizoguchi, Y.; Kanematsu, T.; Hirata, M.; Nabekura, J. A rapid increase in the total number of cell surface functional GABAA receptors induced by brain-derived neurotrophic factor in rat visual cortex. J. Biol. Chem. 2003, 278, 44097-44102. [CrossRef] [PubMed]

37. Palizvan, M.R.; Sohya, K.; Kohara, K.; Maruyama, A.; Yasuda, H.; Kimura, F.; Tsumoto, T. Brain-derived neurotrophic factor increases inhibitory synapses, revealed in solitary neurons cultured from rat visual cortex. Neuroscience 2004, 126, 955-966. [CrossRef]

38. Matsumoto, T.; Numakawa, T.; Yokomaku, D.; Adachi, N.; Yamagishi, S.; Numakawa, Y.; Kunugi, H.; Taguchi, T. Brain-derived neurotrophic factor-induced potentiation of glutamate and GABA release: Different dependency on signaling pathways and neuronal activity. Mol. Cell. Neurosci. 2006, 31, 70-84. [CrossRef]

39. Katoh-Semba, R.; Kaneko, R.; Kitajima, S.; Tsuzuki, M.; Ichisaka, S.; Hata, Y.; Yamada, H.; Miyazaki, N.; Takahashi, Y.; Kato, K. Activation of p38 mitogen-activated protein kinase is required for in vivo brain-derived neurotrophic factor production in the rat hippocampus. Neuroscience 2009, 163, 352-361. [CrossRef]

40. Trang, T.; Beggs, S.; Wan, X.; Salter, M.W. P2 × 4-Receptor-Mediated Synthesis and Release of Brain-Derived Neurotrophic Factor in Microglia is dependent on Calcium and p38-Mitogen-Activated Protein Kinase Activation. J. Neurosci. 2009, 29, 3518-3528. [CrossRef]

41. Yamagishi, S.; Matsumoto, T.; Yokomaku, D.; Hatanaka, H.; Shimoke, K.; Yamada, M.; Ikeuchi, T. Comparison of inhibitory effects of brain-derived neurotrophic factor and insulin-like growth factor on low potassium-induced apoptosis and activation of p38 MAPK and c-Jun in cultured cerebellar granule neurons. Brain Res. Mol. Brain Res. 2003, 119, 184-191. [CrossRef] [PubMed]

(C) 2019 by the authors. Licensee MDPI, Basel, Switzerland. This article is an open access article distributed under the terms and conditions of the Creative Commons Attribution (CC BY) license (http://creativecommons.org/licenses/by/4.0/). 